圤 31 卷 $(1978)$ 第 28 - 298 軗

\title{
東北大学における地震・地殼変動の 検知能力について
}

(I) 微小地震

\author{
東北大学理学部地震予知観測センター 石 井 紘・高 木 章 雄 \\ (昭和 53 年 8 月 17 日受理)
}

\section{On the Detectability of Earthquakes and Crustal Movements in and around the Tohoku District (Northeastern Honshu)}

\section{( I ) Microearthquakes}

\author{
Hiroshi IsHII and Akio TAKAGI \\ Observation Center for Earthquake Prediction, \\ Faculty of Science, Tohoku University \\ (Received August 17, 1978)
}

Fifteen seismological observation stations operated by Tohoku University are distributed in the Tohoku district, northeastern Japanese arc. The accuracy of the determination of hypocenters and origin times of microearthquakes in the Tohoku district is investigated applying the method of prediction analysis.

Contour maps of the estimated standard errors in the hypocenters parameters and origin times are calculated and plotted for several magnitudes and event depths assuming the crust-upper mantle structure and errors in the data, taking into account ground noise level of the observation stations.

\section{1. 序 論}

地震学に括いて，地震波の到達時刻を用いて震源や発現時を求めることは最も基本的な問題 の一つである. 東北大学に括いては, 昭和 49 年度からテレメータによる集中処理方式により 震源決定を実施し，それまでのものと比較してその精度が非常に向上した。そこで東北大学の 観湘網により決定される震源の決定精度や検知能力について調べることを試みた。これは微小 地震のサイスミシティを考光たり，今後，観測点を効果的に増設する場合に非常に有用である. 日本付近の震源決定精度については，すでにいくつかの論文，〔安芸 (1964)，市川 (1967)， SATO, OCHI and KOTAKE (1967), 岸尾・山川 (1969)]により興味ある結果が報告されてい る. 特に SATO, et al. (1967), はシミュレーションを採用し; 観測網の配置による゙観測誤差 昭和 51 年 5 月 11 日発表 
を調べている。この論文では，解析的に種々の誤差を見積るために WOLBERG (1967) による 予測解析法を適用した。この方法は PETERS and CROSSON (1972) が既に震源決定に用いて いる. 我々はより現実的なマグニチュード別の震源決定精度を見積るために各観測点の平均的 グランドノイズを測定し, 計算に取り入れた。震源決定は 4 点以上の $\mathrm{P}$ 波の発現時によるもの とし，層構造を考慮して行うものとした.

\section{2. 東北大学における微小地震観測網}

観測網は現在 15 個所の観測点から構成されており, 各点のデータはテレメータにより伝送 されている. Fig. 1 に観測点配置が示されている. 日本海側の男鹿 (OGA), 二ツ井 (FUT), 化別 (NIB)，沢内 (SAW)，本荘（HOJ）のデータは秋田市にある秋田サブセンターに伝送 され, 太平洋側の階上 (HSK), 姫神 (KHMK), 宮古 (MYK), 三陸 (SNR), 北上 (KGJ) のデータは北上サブセンターに，また，東北南部地域の温海 (ATM), 川渡 (KWT)，釡房 $(\mathrm{KMF})$ ，金華山 $(\mathrm{KNK})$ ，青葉山（AOB）のデータは地震予知観測センターに伝送記銶され る.

回線は電々公社 D1 規格で伝送方式は FM 方式で $4 \mathrm{ch}$ が送られる. さらに, 秋田一青葉 山，北上一青葉山間は 4 線式の D1 回線により結ばれ，秋田と北上に集中された各観測点の上

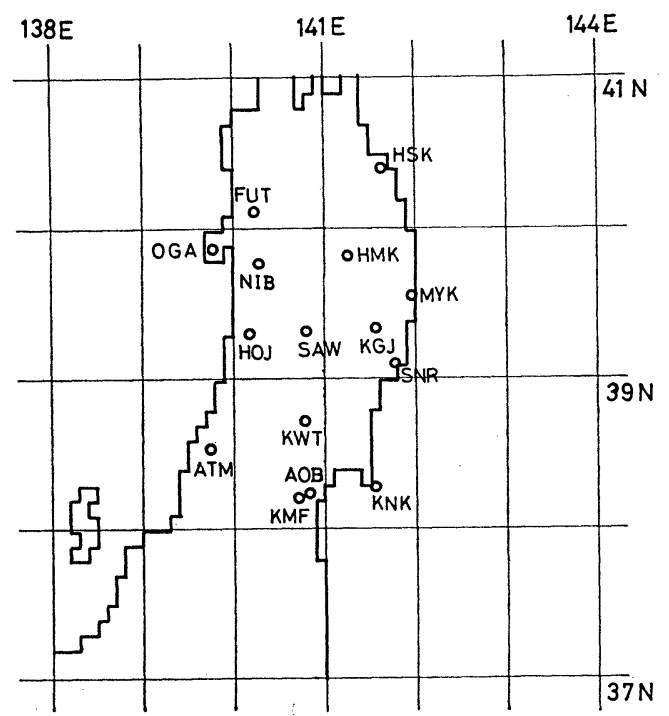

Fig. 1. Locations of seismological observation stations employed for the computation of detectability and accuracy of hypocenters and origin times of earthquakes.
下動 1 成分と HOJ，KGJ の各水平動 1 成分，合計 6 成分ずつの地震記録が 青葉山にオンラインで集中記録される。 このように，青葉山に送られてきた地 震信号は紙送り $2 \mathrm{~mm} / \mathrm{sec}$ のニニー 記録として多成分ペン書き颜録計に常 時記録される。また，全観測点の上下 動成分は地震判定に用いられ, 全点の らち 3 点以上が規定の振幅以上に達し た場合，トリガー信号を秋田と北上サ ブセンターに送る、青葉山と各サブセ ンターの早送り $(15 \mathrm{~mm} / \mathrm{sec})$ 多成分 記録計とアナログデーターレコーダー がこのトリガー信号により駆動され， 遅延時間 $22.5 \mathrm{sec}$ の遅延装置を通つ 
た地震信号を 2 分間記録する.この早送り多成分記録計の記録が人間により $X Y$ 座標読取り 装置により読取られ，計算機とオンラインで結ばれて震源決定に用いられる.

\section{3. 襄源決定精度の計算方法}

この論文では, 種々の観測点配置に対してある地点で発生した地震の震源決定精度を推定す るためにに WOLBERG (1967) よる予測解析法を適用した。 この方法は既に PETERS and CROSSON (1972) によつて地震観測点の局地的配置と震源決定精度の関係に対して適用されて いる. 観測点 $i$ に括ける発震時 $t_{i}$, 観測点の座標や地下構造モデルのパラメータなどを $x_{j i}$, 震源要素などの未知のパラメータを $a_{k}$ としこれらの関係を

$$
t_{i}=f\left(x_{1 j}, x_{2 j}, \cdots, x_{m i} ; a_{1}, a_{2}, \cdots, a_{p}\right)
$$

と表わす。観測值を $T_{i}, X_{j i}$ などとし，残差を次のように定義する.

$$
\begin{aligned}
& R_{t_{i}} \equiv T_{i}-t_{i} \\
& R_{x_{i j}} \equiv X_{j i}-x_{j i}
\end{aligned}
$$

残差の二乘に重み $w_{t_{i}}$ と $w_{x_{j i}}$ を掛けた和 $S$ は

$$
S \equiv \sum_{i=1}^{n}\left[w_{y i} R_{t i}{ }^{2}+\sum_{j=1}^{m} w_{x_{j i}} R_{x_{j i}}{ }^{2}\right]
$$

最小二乗法による震源決定は $S$ を最小にするような $a_{k}$ を求めることである. 関数 $F^{i}$ を

$$
F^{i} \equiv t_{i}-f\left(x_{1 i}, x_{2 i}, \cdots, x_{m i} ; a_{1}, a_{2}, \cdots, a_{p}\right)
$$

と定義すると（1）より

$$
F^{i}=0, i=1,2, \cdots, n
$$

また, 関数 $F$ の微分を添字によつて次のように表わす:

$$
F_{x_{j}}{ }^{i} \equiv \frac{\partial F^{i}}{\partial x_{j i}} ; F_{\iota}{ }^{i} \equiv \frac{\partial F^{i}}{\partial t_{i}}=1 ; F_{a_{k}}{ }^{i} \equiv \frac{\partial F^{i}}{\partial a_{k}}
$$

データや未知パラメータの第一近似 $a_{k 0}$ から推定される $F^{i}$ の值を $F_{0}^{i}$ とすると

$$
F_{0}{ }^{i} \equiv T_{i}-f\left(X_{1 i}, X_{2 i}, \cdots, X_{m i}, a_{10}, a_{20}, \cdots, a_{p 0}\right)
$$

ここで $F_{0}{ }^{i}$ はゼロに等しくない，未知パラメータの補正值を $A_{k}$;

$$
A_{k} \equiv a_{k 0}-a_{k}
$$

とすると $A_{k}$ は次の連立方程式を解くことによつて得られる.

$$
\begin{gathered}
A_{1} C_{11}+A_{2} C_{12}+\cdots+A_{p} C_{1 p}=V_{1} \\
\vdots \\
A_{1} \dot{C}_{p 1}+A_{2} C_{p 2}+\cdots+A_{p} C_{p p}=\dot{V}_{p}
\end{gathered}
$$

ここで

$$
C_{k l} \equiv \sum_{i} L_{i}^{-1} F_{a_{k}}^{i} F_{a_{l}}^{i}
$$




$$
\begin{aligned}
V_{k} & \equiv \sum L_{i}{ }^{-1} F_{a_{l k}}{ }^{i} F_{0}{ }^{i}, \\
L_{i} & \equiv \frac{\left(F_{t}^{i}\right)^{2}}{w_{t_{i}}}+\sum_{j=1}^{m} \frac{\left(F_{x j}{ }^{i}\right)}{w_{x_{j i}}} \\
k & =1,2, \cdots, p \\
l & =1,2, \cdots, p \\
i & =1,2, \cdots, n
\end{aligned}
$$

WOLBRG (1967) によると末知数 $a_{k}$ の標準偏差 $\sigma_{a_{l}}$ の予測値は,

$$
\hat{\sigma}_{a_{k}} \sim\left(\frac{S}{n-p}\right)^{1 / 2} \cdot\left(C_{k k}^{-1}\right)^{1 / 2}, k=1,2, \cdots, p
$$

より推起される． $S$ が $x$ 二乘分布に従うならば $S$ の平均値 $\hat{S}$ は

$$
\hat{S}=n-P
$$

となり，(11）式より $\sigma_{a_{k}}$ の予测值 $\hat{\sigma}_{a_{k}}$ は

$$
\hat{\sigma}_{a_{k}}^{2}=C_{k k}^{-1}
$$

から推定できる、従つて, 我々は実際のデータの逐次近似によつて解を求めることなしに与え ら礼たデータの組だけから未知睹の標準偏差を計算することができる，以上の結果を用いて震

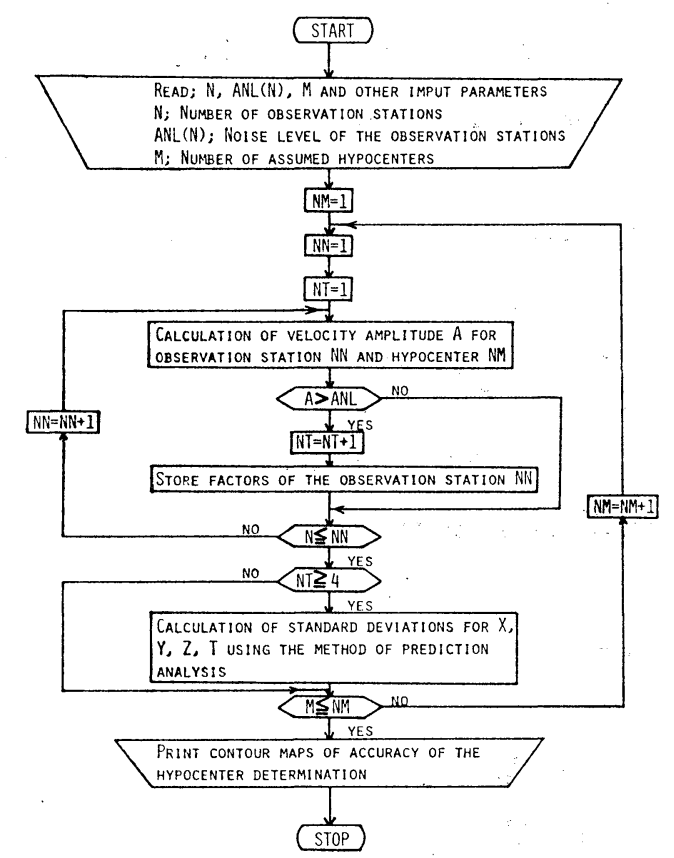

Fig. 2. Flow chart employed for the computation of detectability and accuracy of hypocenters and origin times of earthquakes.
源決定精度を試算した。震源決管は初 動によるものとし，4点以上で観測さ れた場合の夕計算するものとした，震 源を北緯 $37^{\circ} \sim 41^{\circ}$, 東経 $138^{\circ} \sim 144^{\circ}$ の範囲の $0.1^{\circ}$ ごとに仮定し, その全 てに対して決定精度を計算した。計算 のブロックダイアグラムが Fig. 2 に 示されている，まず，仮定した震源に 対して, 各観測点で期待される速度振 幅を村松 (1964) の式により計算し, それと各観測点に抢ける平均的グラン ドノイズと比較し, 計算された振幅が グランドノイズの 2 倍より大きい場合 に初動が読取れるとした。村松の式は 最大振幅に対するものであるが，種々 の条件を課した場合の結果と実際の決 

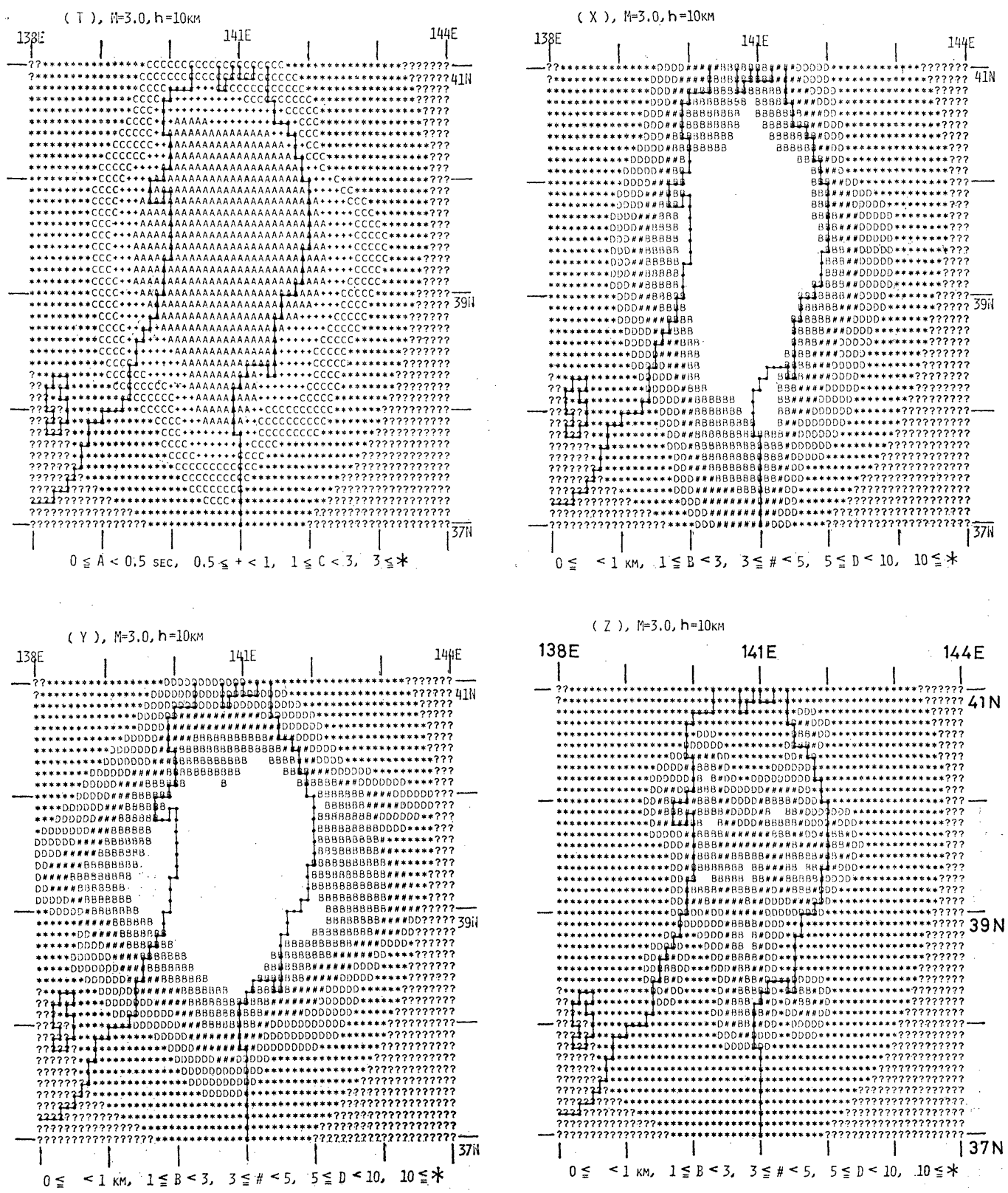

Fig. 3 (a), (b), (c), (d). Maps showing datectability and accuracy of hypocenters and origin time for earthquakes with the magnitude of 3.0 and the depth of $10 \mathrm{~km}$, assuming a semiinfinite elastic medium with $\mathrm{P}$ wave velocity of $6 \mathrm{~km} / \mathrm{sec}$. Alphabets, T, X, Y and $\mathrm{Z}$ mean origin time, E-W component, N-S component and depth respectively. Accuracies are represented by the signs shown below the figures. Question marks mean that a seismic $\mathrm{P}$ wave larger than the ground noise level can not be caught at the stations more than four stations. 
定を比較し，経験的に上述の条件を採用した。

初動の読み取りには 0.05 秒の標準偏差を仮定し, 地下構造の速度には $0.1 \mathrm{~km} / \mathrm{sec}$, 深さ には $0.1 \mathrm{~km}$ の標準偏差を仮定した。

\section{4. 罘源決定精度と検知能力}

\section{(a) 全体的特徵}

第 1 段階として地下構造は半無限弾性体で $\mathrm{P}$ 波の速度を $6 \mathrm{~km} / \mathrm{sec}$ と仮定し, 4 点以上で検 知されたものにてついて発現時 (P time) を用いて震源を決定するものとした. Fig. 3 は $M$ $=3$ で, 深さ $h=10 \mathrm{~km}$ の地震に対する震源決定精度を計算したものである. $X, Y, Z$ は, それぞれ東西，南北，深さの方向の震源決定精度の標準偏差を示し， $T$ は発震時のそれを示 す. 記号は $X, Y, Z$ に関しては標準偏差が次のような意味をもつ. ブランク $1 \mathrm{~km}, 1 \mathrm{~km}$ $<B \leqq 3 \mathrm{~km}, 3 \mathrm{~km}<\# \leqq 5 \mathrm{~km}, 5 \mathrm{~km}<D \leqq 10 \mathrm{~km}, *>10 \mathrm{~km}, ?=4$ 点以上では検知不能. また, $T$ に関しては $0 \leqq \mathrm{~A}<0.5$ 秒, 0.5 秒 れらの記号は後の図においても同様に用いられる。このような半無限弾性体によつても観測点 配置の特徽が大体理解できる. $X, Y, Z$ と $T$ は戦純なパターンを示しているが，深さ $Z$ は 複雑なパターンを示している. 東北大学の観測点配置が南北に伸びているため, 東西方向の震
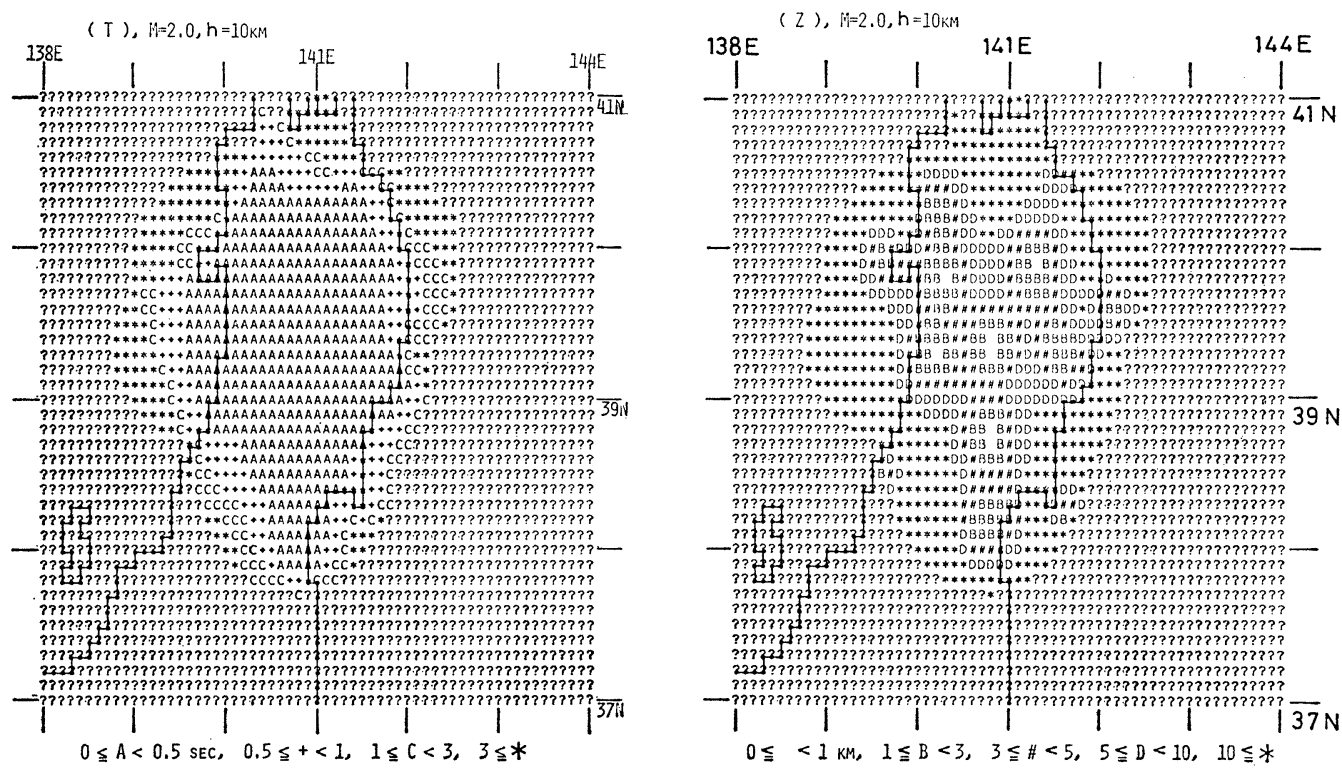

Fig. 4 (a), (b). Maps showing detectability and accuracy of depth (Z) and origin time (T) for earthquakes with the magnitude 2.0 and the depth of $10 \mathrm{~km}$, assuming the same elastic model as Fig. 3. Meaning of the marks is shown below the figures and the same as Fig. 3. 
( T ) $, H=3,0, h=10 \mathrm{KM}, H=31 \mathrm{kM}$

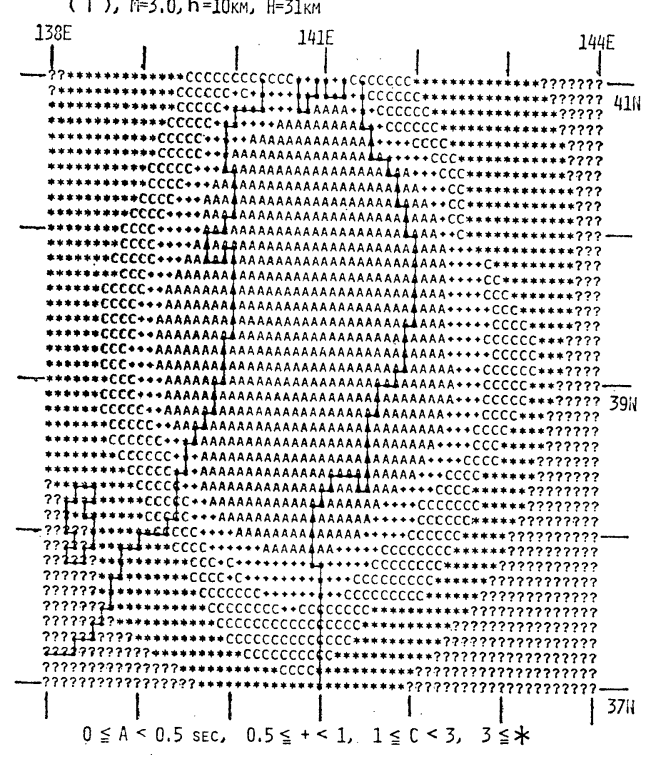

( $\gamma$ ), $\mathrm{H}=3.0, \mathrm{~h}=10 \mathrm{kin}, \mathrm{H}=31 \mathrm{kM}$

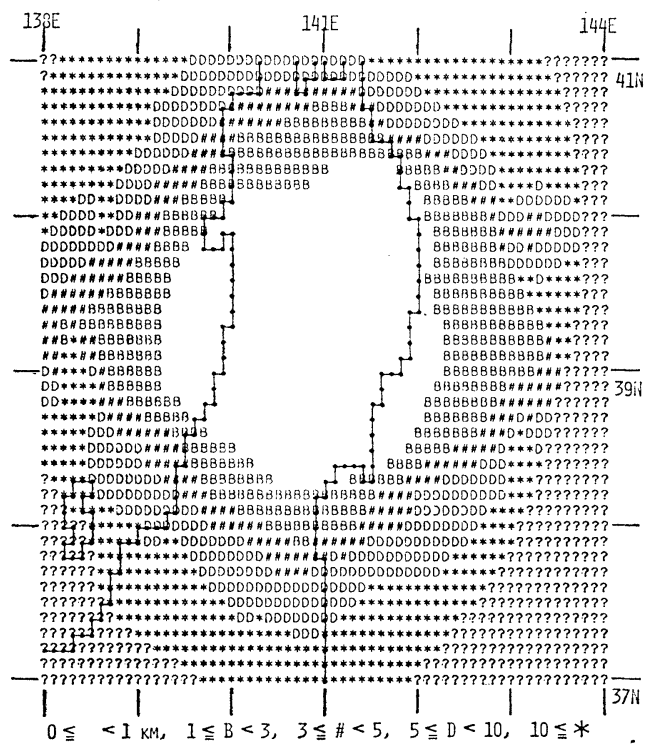

( $X), \quad H=3.0, h=10 \mathrm{kM}, \quad H=31 \mathrm{kM}$

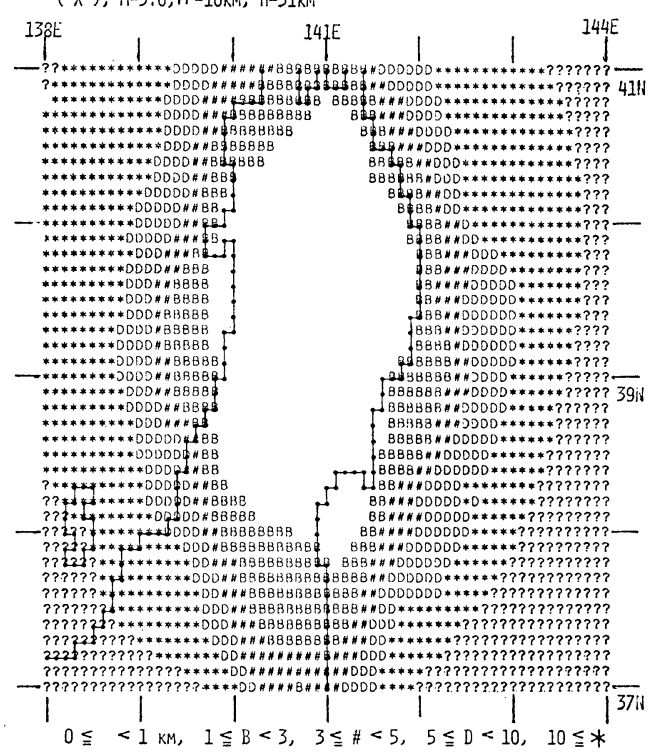

( Z ) $M=3.0, h=10 \mathrm{KM}, H=31 \mathrm{KM}$

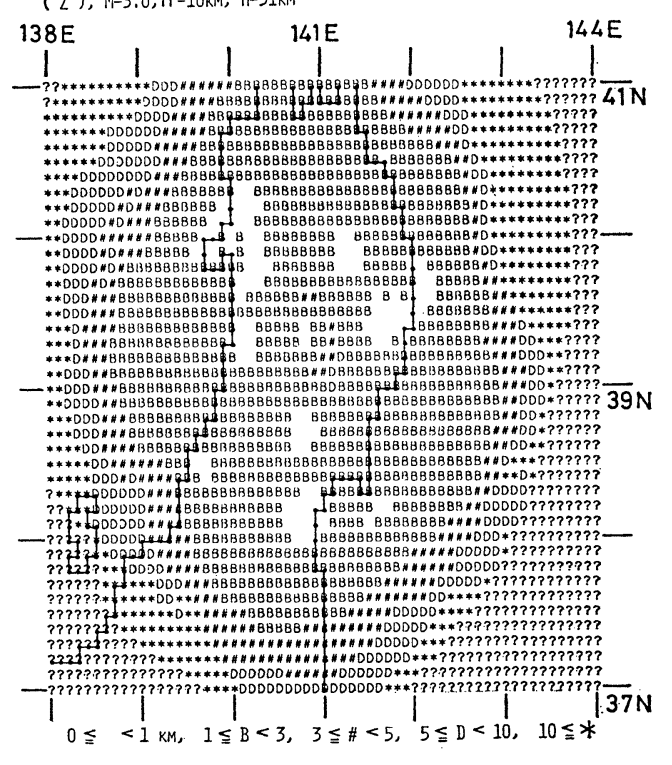

Fig. 5 (a), (b), (c), (d). Maps showing detectability and accuracy of hypocenters and origin time for earthquakes with the magnitude of 3.0 and the depth of $10 \mathrm{~km}$, assuming a crustupper mantle model with a $P$ wave velocity of $6.3 \mathrm{~km} / \mathrm{sec}$ in the crust and $8.0 \mathrm{~km} / \mathrm{sec}$ in the mantle, and a thickness of the crust of $31 \mathrm{~km}$. Alphabets, T, X, Y and $\mathrm{Z}$ mean origin time, E-W component, N-S component and depth. Meaning of the marks is shown below the figures and the same as Fig. 3. 

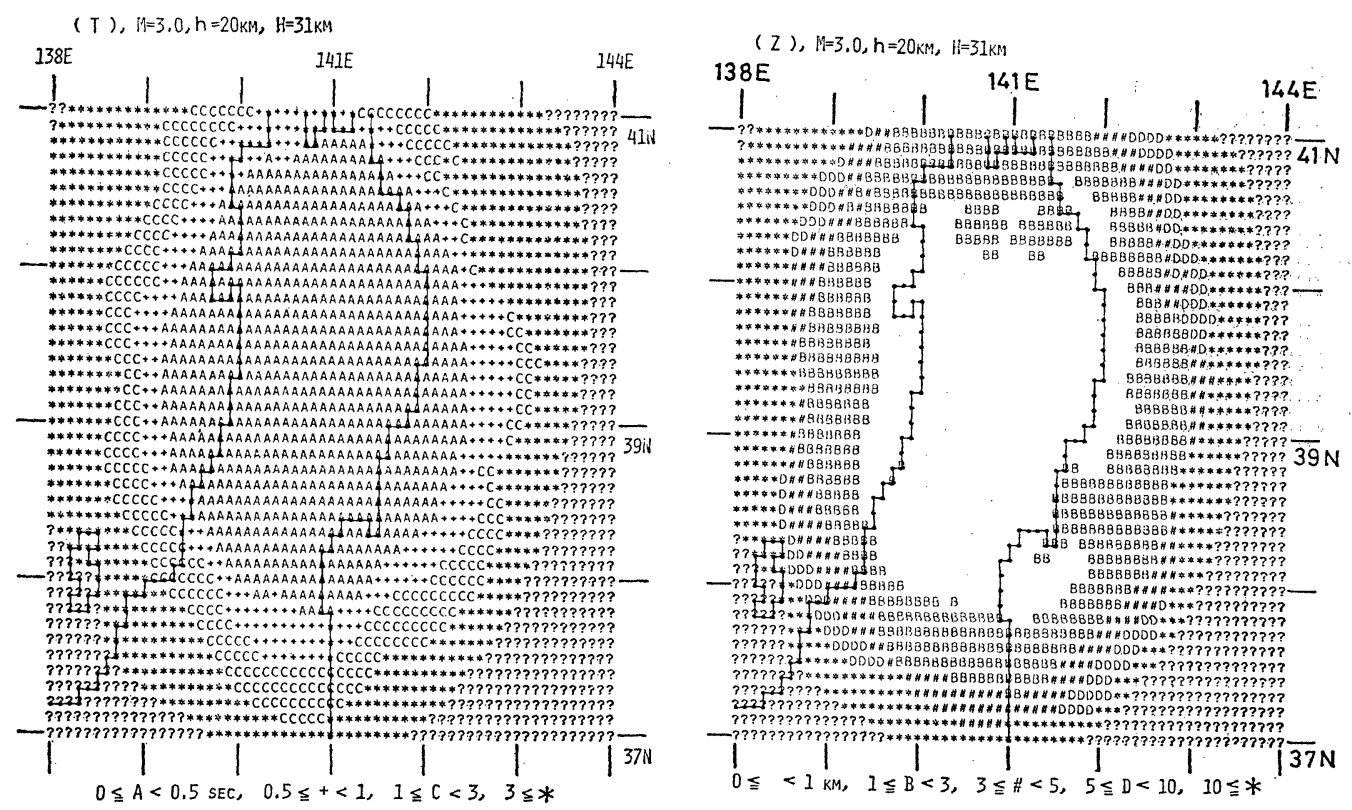

Fig. 6 (a), (b). Maps showing detectability and accuracy of depth (Z) and origin time (T)

for earthquakes with the magnitude of 3.0 and the depth of $20 \mathrm{~km}$, assuming the same elastic model as Fig. 6. Marks have the same meaning as Fig. 5.

源決定精度の図は南北に長くなり，南北方向の決定精度は東西方向に伸びる傾向がある，発震 時に関しては $X$ と $Y$ の平均的な図になつている. 深さ方向の精度の図は複雑で全体的に $X$ や $Y$ よりも精度が悪くなつているのがわかる.

\section{(b) マグニチュードによる相違}

地震のマグニチュードの相違による検知能力の変化を調べるため半無限弾性体で深さ $10 \mathrm{~km}$ にマグニチュード 2.0 の地震が起こつた場合の震源決定精度が Fig. 4 に示してある. Fig. 3 と比較してみるとわかるように検知可能な範囲が非常に小さくなるのがわかる。しかしながら， 震源決定精度についてみると内陸部においては $M=3$ と $M=2$ の場合で注とんど差がない.

\section{(c) 地下構造による相違}

震源決定の際に用いる地下構造モデルにより震源決定精度がどの程度影響されるか調べてみ

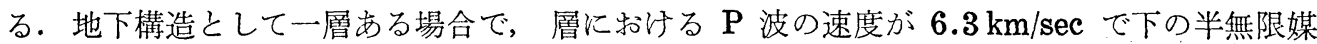
質に拈ける速度が $8.0 \mathrm{~km} / \mathrm{sec}$ で層の厚さが $31 \mathrm{~km}$ というモデルを採用した．Fig. 5 はこの 地下構造で Fig. 3 と比較するために震源の深さ $10 \mathrm{~km}$ でマグニチュードは 3.0 の場合の震 源決定精度を計算したものであるＦig. 3 と比較してみると次のことがわかる．すなわち， 検知可能な範囲やパターンはほんんど同じであるが，決定精度のよい領域が全体的に広がつて いる. この特徵は深さの決定精度の図に対して特に顕著であり，Fig. 1 と此較すると精度が 
(T ), $M=1.5, h=30 \mathrm{kM}$

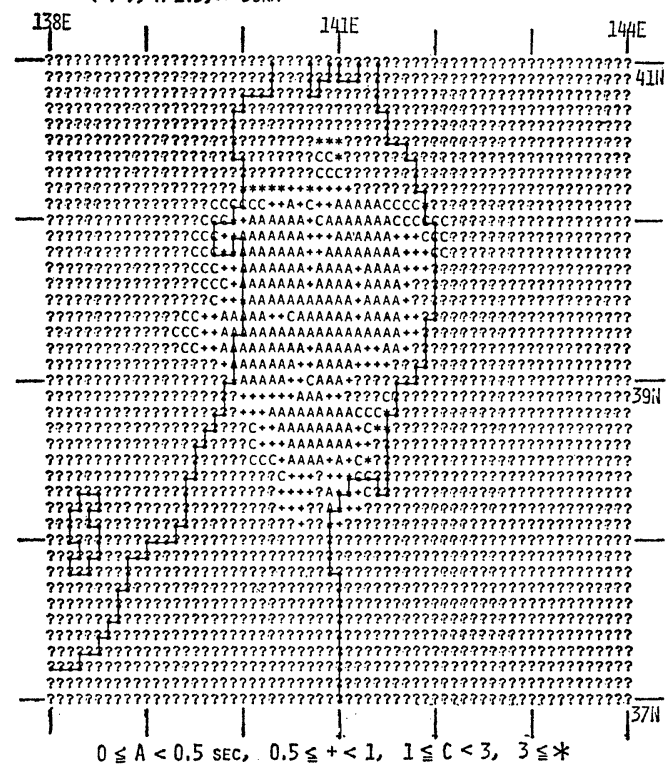

( $(\mathrm{z}), \mathrm{H}=1.5, \mathrm{~h}=30 \mathrm{kM}$

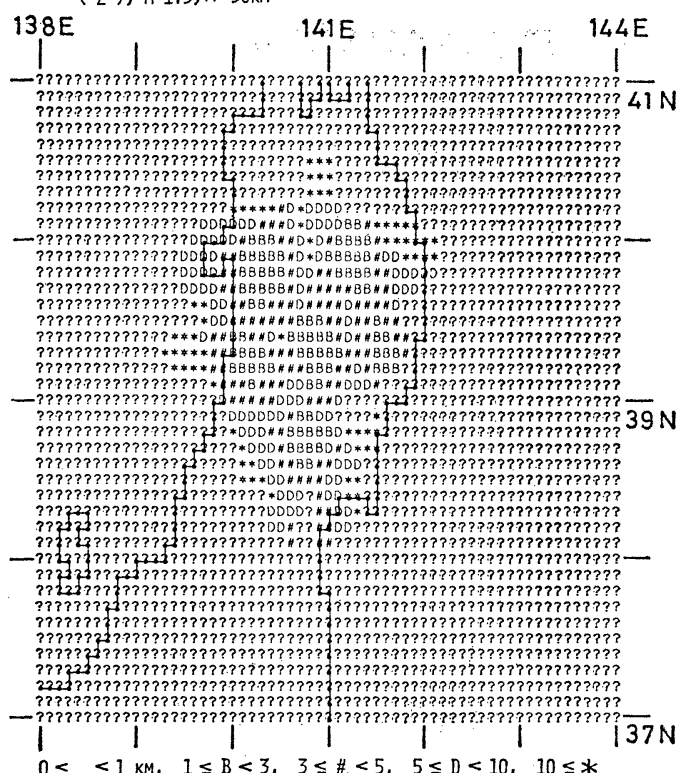

Fig. 7 (a), (b). Maps showing detectability of depth (Z) and origin time (T) for earthquake with the magnitude of 1.5 and depth of $30 \mathrm{~km}$, considering all stations and assuming the same elastic model as Fig. 3. Marks have the same meaning as Fig. 5.

(T ), $l=1.5, h=30 \mathrm{KM}$

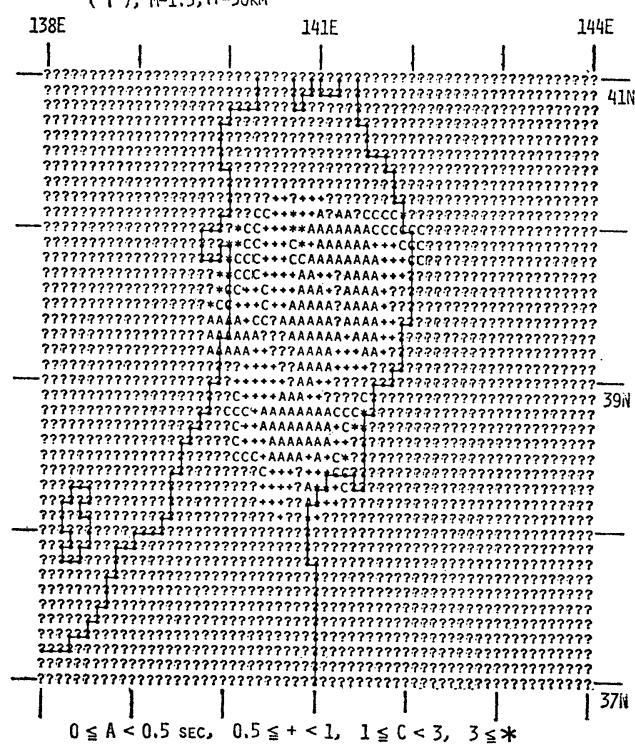

( $z), H=1,5, h=30 \mathrm{~km}$

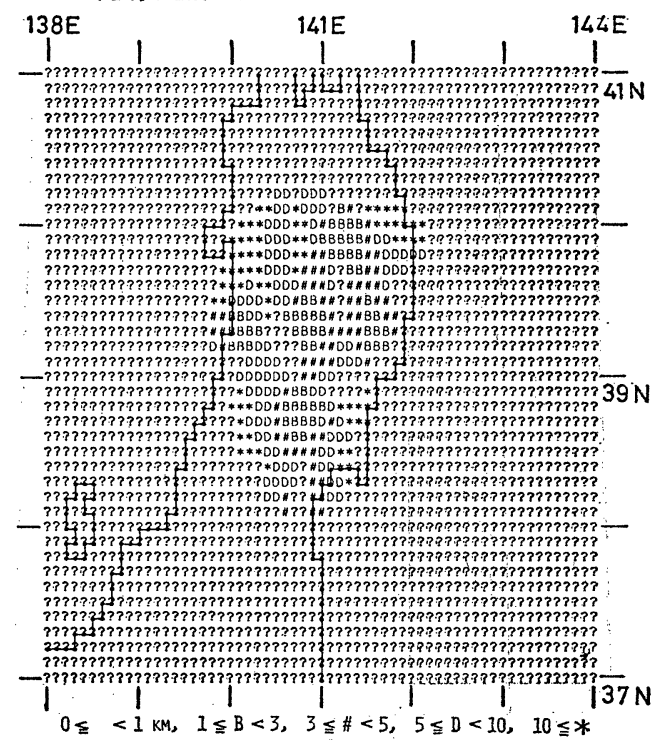

Fig. 8 (a), (b). Maps showing detectability of depth (Z) and origin time $(T)$ for earthquakes with the magnitude of 1.5 and depth of $30 \mathrm{~km}$, not consideing the NIB station and assuming the same elastic model as Fig. 3, Marks have the same meaning as Fig. 5. 
非常に向上し，かつその領域の拡大しているのが明白である.

\section{（d）震源の深さによる相違}

震源の深さが震源決定精度に及洔す影響を次に調べる．Fig. 5 と比較するために同じ一層 構造で深さが $20 \mathrm{~km}$ の震源の場合の決定精度の図が Fig. 6 である. $X, Y$ と $T$ の図では 震源の深さが異なつても検知可能範囲も, 決定精度もほとんど変らない. しかるに, 深さに関 する決定精度の図 $Z$ をみると精度の高くなる領域が拡大し, 東北地方内陸のほとんどで $1 \mathrm{~km}$ 以内で深さが求まるのがわかる．震源の深さは深さ方向の決定精度に非常に影響している.

\section{(e) 観測点の貢献度}

全体の観測網の中で，ある観測点がぞの程度貢献しているかを調べてみる．これは今後観測 点を増設する場合にどの程度検知能力が向上するかを予測し, 最適の観測点を決める場合など の際に重要である. 半無限媒質で, 震源の深さが $30 \mathrm{~km}$, マグニチュード 1.5 の場合の決定 精度が Fig. 7 に示してある. マグニチュードが小さいので検知可能範囲が非常に狭くなつて いる. 全体の観測網の中で NIB (仁別) 観測点がない場合の震源決定精度を示したのが Fig.8 である. 男鹿半島や秋田市沖の地震が注とんど検知できず, 内陸の西側の地震の決定精度も悪 くなつているのがわかる.

内陸太平洋側の地震に関しては, 他の観測点で充分であり, NIB観測点のない影響はほとん ぞない。このような数值実験を試みることは, 観測点の増設場所を決める際などに有用である.

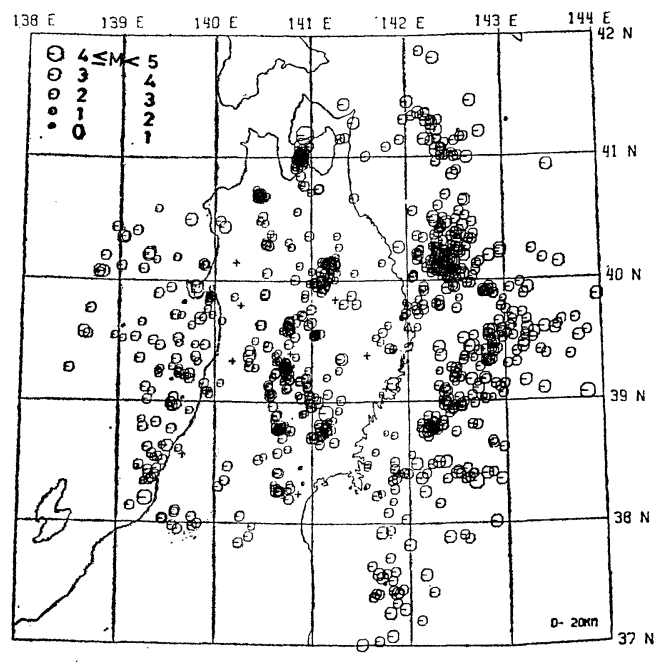

$26.1 .1-7 E . \mathrm{i} 2.3 \mathrm{i}$

Fig. 9. Epicenter distribution of shallow earthquakes with depth less than $20 \mathrm{~km}$ in the Tohoku district for a year of 1976 .

\section{5. 議 論}

1976 年と 1977 年に東北大学の地震 観測網により観測され震源決定された 微小地震の震央分布が Fig. 9 と Fig. 10 に示してある. 深さは $20 \mathrm{~km}$ までの 浅い地震である。この震源決定に用い られている地下構造は地殼の中で $\mathrm{P}$ 波 の速度が 1 次的に増加しているような モデル（長谷川武司他(1974)）で震源 決定にはAKI (1965) の方法を適用 している. 東北地方の浅い地震の震央 分布に関して次のような特性が見られ る.すなわち，三陸沖から aseismic 
front までの微小地震活動の活発な地 域がある。これは沈み込む海洋プレー トと大陸プレートとの相互作用により 起こると考光られる．次に，東北地方 内陸に発生している微小地震は火山フ ロントと一致している. 青森県にみら れる活動地域は岩木山の火山性地震活 動と陸奥湾の群発地震活動である。ま た，日本海側では男鹿半島や秋田沖付 近に扔いて活動域があり, 新潟地震 (1964 年) の余震とみられる活動も顕 著である。

前述の図からわかると扮り, 日本海 側の NIB や HOJ の観測点はグラン

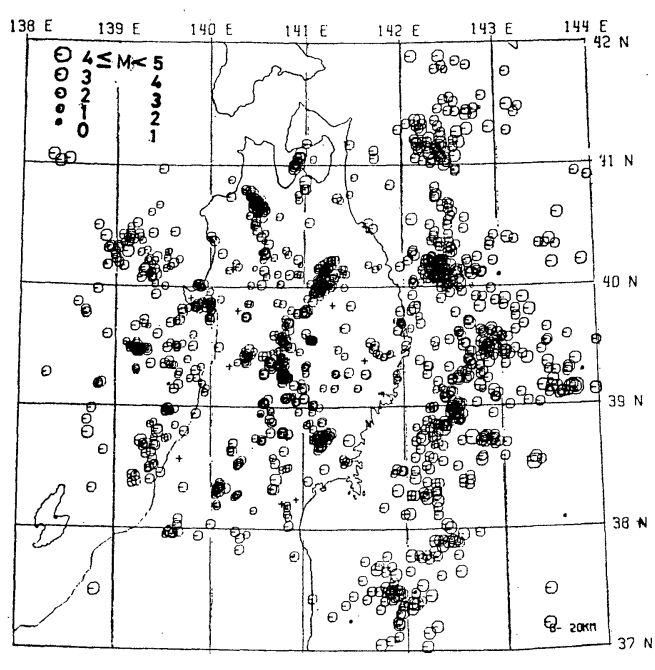

77. $1.1-77 \cdot 12 \cdot 31$

Fig. 10. Epicenter distribution of shallow earthquakes with depth less than $20 \mathrm{~km}$ in the Tohoku district for a year of 1977 .

ドノイズが他より小さく, そのために, 特に日本海側の検知能力がよくなつていることから, 日本海のはるか沖には微小地震活動はないことが明らかである. 東北地方南部, 福島県南部は 検知能力の限界付近であることにより活とんど震源が決まつていない.

決定された震央分布が前述の $M=3$ の場 合の検知可能範囲と同様な形をしているのがわか る. Fig. 9 と Fig. 10 の震源決定は人間がアナログ記録を直接みて，P 波の到達時を判定し たものであり, ノイズの比較的大きい場合でも, 種々の判断が可能である. したがつて, ノイ ズと信号の比の条件で作成した前述の検知能力図よりも検知範囲が広がつている．また，実際 には地下構造の水平方向の異方性なども考えられるから計算された図とは若干の相違が考元ら れる. 以上のことから, 東北大学のネットによつて $M=2.5$ 以上ならば確実で, $M=2$ 以上 の地震ならば，注もれなく検知されていると考えられる。

\section{6. 結 論}

東北地方に配置された 14 個所の微小地震観測点（現在は 15 個所）により決定される震源 の決定精度について調べた。用いた方法は，PETERS and CROSSON（1972）に既に適用してい る WORBERG (1967) の予測解析法である. 震源決定は 4 点以上で観測された $\mathrm{P}$ 波初動を用 いるものとし, 地下構造は地殼とマントルの成層構造を仮定した. 震源を北緯 $37^{\circ} \sim 41^{\circ}$, 東 経 $138^{\circ} \sim 144^{\circ}$ の範囲で $0.1^{\circ}$ ごとに仮定した. 異なるマグニチュードに対する震源決定精度 
を得るために各々の震源に対して各観測点で期待される速度振幅を村松 (1964) の式により計 算し, 各観測点のグランドノイズと比較してあるレベルよりも大きい場合に初動が読み取れる

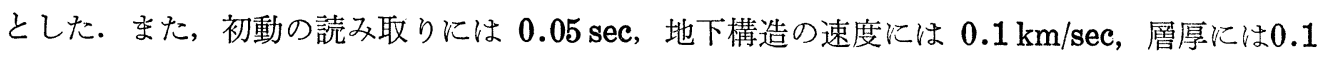
$\mathrm{km}$ の標準偏差を仮定し，次のような主な結果が得られた。

（1）東西方向, 南北方向, 深さと発震時に対する震源決定精度の分布図が得られ, 観湘点 配置と各点のグランドノイズを反映した特徴を示していることがわかつた.

（2）マグニチュードの相違により検知可能範囲は著しく変わるが，東北地方内陸部に関し ては震源決定精度はほとんど差がない.

（3）用いた地下構造が半無限の場合よりも一層構造の場合の方が震源決定精度は非常に向 上する。

（4）震源の深さが $10 \mathrm{~km}$ 程度では，深さの方向の決定精度の分布図が著しく複雑になる.

（5）この方法により観測点の貢献度が調べることが容易であり, 一例として NIB 観測点 のない場合を調べた、観測点の廃止や増設を検討する際に有効である.

（6）実際に決定された震源分布と比較することによりマグニチード 2.0 以上の地震は検知 可能であると考えられる.

\section{謝 辞}

この研究を進める過程において討論と有益な助言をしていただいた地震予知観測センターの 平沢教授はじめ, 地震・地殼变動観測所の皆様に心から感謝致します.

また，論文のタイプや図の作成を手伝つていただいた榊乃理子嬢にもここに記して感謝致し ます。

\section{文献}

AKI K., 1964, Accuracy of Origin Time, Epicenter and Focal Depth of Local Earthquake Determined Routinely by the Japan Meteorological Agency, Bull. Earthq. Res. Inst. 43, 23-38.

市川政治，1967，日本に㧊ける地震波の走時抢よび振幅，気象庁技術報告，第 55 号，1-42.

村松郁栄, 1964, Magnitude の定義式について, 地震 II, 210-221.

Peters, D.C. and R. S. Crosson 1972, Application of Prediction Analysis to Hypocenter Determination Using a Local Array, Bull. Seism. Soc. Amer., 62, 775-788.

SATô, Y., I. OCHI and Y. KoTAKe, 1967, Accuracy of the Determination of Earthquake Source Parameters in and around Japan, Bull. Earthq. Res. Inst., 45, 1-5.

Wolberg, J. R., 1967, Prediction Analysis, D. Van Nostrand Co. Inc., Princeton, N. J. 